\title{
A Comparative Study of the effects of Vitamins C and E in the Development of Sarcoma 180 in Mice
}

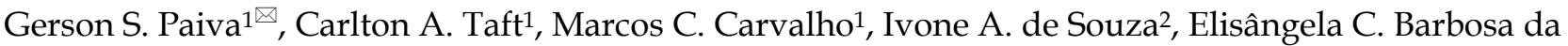 \\ Silva2 ${ }^{2}$ Karen P. Cavalcanti², Ronaldo F. L. Jr. ${ }^{3}$, Neil M. De la Cruz ${ }^{4}$ \\ 1. Centro Brasileiro de pesquisas Físicas, Rua Dr.Xavier Sigaud, 150, 22290-180, Rio de Janeiro, Rio de Janeiro, Brazil \\ 2. Centro de Ciências Biológicas, Departamento de Antibióticos, Universidade Federal de Pernambuco, 1235, 50670-901, Recife, Pernam- \\ buco, Brazil \\ 3. Departamento de Química, Universidade Católica de Pernambuco, Rua do Principe, 526, 50050-900, Recife, Pernambuco, Brazil \\ 4. Departamento de Física, Pontifícia Universidade Católica do Rio de Janeiro Rua Marquês de São Vicente, 225, 22450-900, Rio de Janeiro, \\ Rio de Janeiro, Brazil
}

$\bowtie$ Corresponding author: gersonspaiva@ufpe.br

( ) Ivyspring International Publisher. This is an open-access article distributed under the terms of the Creative Commons License (http://creativecommons.org/ licenses/by-nc-nd/3.0/). Reproduction is permitted for personal, noncommercial use, provided that the article is in whole, unmodified, and properly cited.

Received: 2013.01.21; Accepted: 2013.06.02; Published: 2013.11.16

\begin{abstract}
In this work we have investigated the effects of vitamins $C$ and $E$ on tumors via the mice xenotransplant model of sarcoma $180\left(\mathrm{~S}_{180}\right)$ in vivo. The experimental results suggest that dosages of $100 \mathrm{mg} / \mathrm{kg}$ vitamin $\mathrm{C}$ and $400 \mathrm{mg} / \mathrm{kg}$ vitamin $\mathrm{E}$ yields a great inhibitory behavior on tumors.
\end{abstract}

Key words: Vitamin C, Vitamin E, Sarcoma 180, mice

\section{Introduction}

Antioxidants are widely used in dietary supplements and have been investigated for the prevention of diseases such as cancer, coronary heart disease and even altitude sickness [1]. Vitamin $C$ is found in high concentrations in immune cells, and is consumed quickly during infections [2-3]. Vitamin $C$ has been hypothesized to modulate the activities of phagocytes, the production of cytokines and lymphocytes, and the number of cell adhesion molecules in monocytes [4]. On the other hand, vitamin E supplementation induces a higher differentiation of immature $T$ cells via increased positive selection by thymic epithelial cells, which results in the improvement of decreased cellular immunity in the aged. When there is vitamin E deficiency most of the immune parameters show a downward trend, which is associated with increased infectious diseases and the incidence of tumors [5]. Antioxidants don't always protect us from cancer. Some tumor cells can actually use antioxidants to protect themselves from natural cellular defense mechanisms, enabling them to survive and proliferate. Joan Brugge et al. [6] were investigating changes in breast cancer cells that allow them to survive without being attached to the normal extracellular matrix. They found that treating cells with vitamin E-like antioxidants blocked the usual programmed cell death cycles, allowing the cells to survive free from their usual scaffolding by switching their metabolism to use fatty acids rather than glucose as fuel [6]. Liu and Liu indicated that administration of vitamin E prevents thymocyte apoptosis in murine $S_{180}$ tumor bearing mice [7]. Vitamins are important for the growth of both human and animal tissues. Fodor and Kunos [8] reported that subcutaneous injection of vitamin $C$ in tumor mice resulted in a great increase in the size, whereas Pollia [9] apparently did not observe a similar effect on the growth in vivo of a malignant dibenzanthracene tumor of the rat.

In this work, we conducted a comparative study of vitamin $C$ and $E$ in the development of sarcoma 180 in mice. These vitamins showed significantly $(\mathrm{P}<0.00001)$ improved great anticancer activity for dosages on the order of $100 \mathrm{mg} / \mathrm{kg}$ (vitamin C) and $400 \mathrm{mg} / \mathrm{kg}$ (vitamin E). 


\section{Materials and methods}

\section{I. Development of the mouse tumor model}

Transplantation of Sarcoma 180 tumor was performed following the method of Stock et al [10] and modified by Komiyama [11]. $S_{180}$ cells (106 cells/mouse) were implanted intraperitoneally into male albino mice.

\subsection{Statistical analysis}

Data were analyzed by Student's $t$-test using the statistical program StudyResult (version 1.0 for Windows).

\subsection{Grouping and administration of drugs}

The treatment started 48 hours after tumor implantation. Forty-eight animals were examined in this study. Mice were randomly divided into vitamin C and vitamin E-treated groups, respectively, to receive vitamin C (100; $200 \mathrm{mg} / \mathrm{kg} /$ day for 7 days in $1 \mathrm{ml}$ of normal saline) administered orally and vitamin $\mathrm{E}$ (100; $200 \mathrm{mg} / \mathrm{kg} /$ day for 8 days in $1 \mathrm{ml}$ of normal saline) by oral administration. Six days after tumor implantation, the animals were weighed, anesthetized by ether inhalation and killed by cervical dislocation, and the tumors carefully excised and weighed. The negative control group was given normal saline $(0.9 \%)$ of the same volume according to body weight. Statistical methods were based on Snedecor and Cochran [12]. The experiment was repeated three times. The results were identical for each dose. The animals were handled under the supervision of the Ethics Committee of the Centro de Ciências Biológicas (CCB) da Universidade Federal de Pernambuco, Recife, Pernambuco, Brasil.

\section{Results and discussions}

Figure 1 and Tables 1-2 show the results. The mean tumor weight of $S_{180}$ in the vitamin E-treated group was lower than that in the vitamin C-treated group.

The tumoral inhibition is given by [10]:

$$
I \%=\left(\frac{C-T}{C}\right) \times 100
$$

where $C$ is the mean tumor mass of control group, $T$ is the mean mass of treated group. From Table 1 and Figure 1. We observe that for large dosages of either vitamin $C$ and vitamin $E$ the mice died. For intermediate dosages the inhibitory effect of vitamin $C$ is dosage-dependent. Most cells express two different transporter systems for vitamin C; a transporter system with absolute specificity for ascorbic acid and a second system that shows absolute specificity for dehydroascorbic acid [13]. Ascorbic acid is transported by the SVCT family of sodium-coupled transporters, with two isoforms molecularly cloned, the transporters SVCT1 and SVCT2, which show different functional properties on different cell and tissue expression. Probably, the not linear inhibitory effect of vitamin C is caused by the saturation of SVCT2 and SVCT1 transporters inside tumor cells but only for vitamin C doses between 100 and $400 \mathrm{mg} / \mathrm{kg}$.

However all experiments with different dosages indicates that appropriate dosages of vitamin $\mathrm{E}$ appear to have a better inhibitory behavior for the tumors than vitamin C. Although more detailed investigation is necessary, the present results suggest that, at least for mice, $400 \mathrm{mg} / \mathrm{kg}$ vitamin $\mathrm{E}$ appears to be an ideal dosage for tumor inhibition. On the other hand, there is significant statistical difference between the treatment with vitamin $\mathrm{C}$ and vitamin $\mathrm{E}, \mathrm{P}<$ 0.00001 for tumor development in animals by Student's $t$-test.

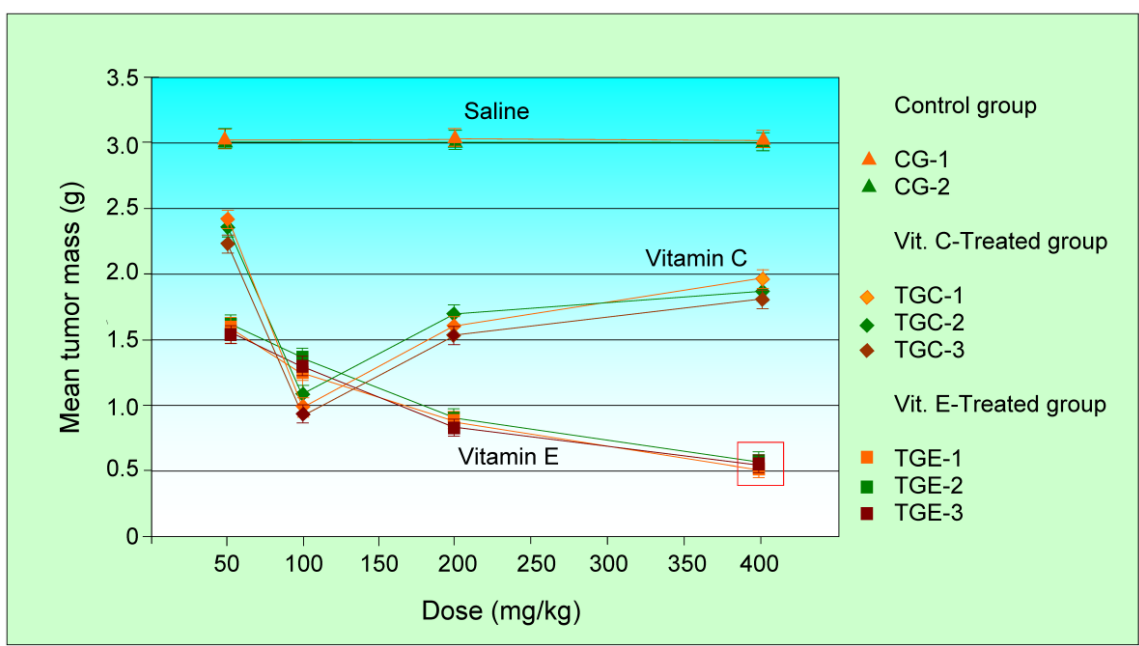

Figure I. The mean mass of the sarcoma 180 tumors as a function of the administrated dose. Significant changes are indicated by red rectangles. Vitamin E-treated group: 16 animals; vitamin C-treated group: 16 animals; Control group: 16 animals. 
TABLE I. INHIBITION EFFECTS OF VITAMIN C ON SI80 ENTITY TUMOR MICE $(X \pm S)$. Lethal dose $\left(L_{50}\right)$ of vitamin $C=$ $12000 \mathrm{mg} / \mathrm{kg}$;

\begin{tabular}{|c|c|c|c|c|}
\hline \multicolumn{2}{|l|}{ Groups } & \multirow{2}{*}{$\begin{array}{l}\begin{array}{l}\text { Dose } \\
(\mathrm{mg} / \mathrm{kg})\end{array} \\
-\end{array}$} & \multirow{2}{*}{$\begin{array}{l}\begin{array}{l}\text { Mean tumor } \\
\text { mass }(\mathrm{g})\end{array} \\
3.050 \pm 0.001 \\
\end{array}$} & \multirow{2}{*}{$\begin{array}{l}\text { \% inhibi- } \\
\text { tion } \\
-\end{array}$} \\
\hline Control & CG-1 & & & \\
\hline \multirow{12}{*}{ 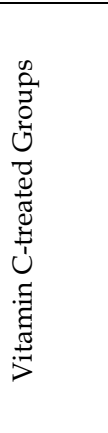 } & \multirow{4}{*}{ TGC-1 } & 50 & $2.400 \pm 0.001$ & 21.3 \\
\hline & & 100 & $0.993 \pm 0.001$ & 67.4 \\
\hline & & 200 & $1.547 \pm 0.001$ & 49.2 \\
\hline & & 400 & $1.870 \pm 0.001$ & 38.7 \\
\hline & \multirow{4}{*}{ TGC-2 } & 50 & $2.750 \pm 0.001$ & 9.8 \\
\hline & & 100 & $1.200 \pm 0.001$ & 60.7 \\
\hline & & 200 & $1.602 \pm 0.001$ & 47.5 \\
\hline & & 400 & $1.770 \pm 0.001$ & 41.9 \\
\hline & \multirow{4}{*}{ TGC-3 } & 50 & $2.350 \pm 0.001$ & 22.9 \\
\hline & & 100 & $0.882 \pm 0.001$ & 71.1 \\
\hline & & 200 & $1.500 \pm 0.001$ & 50.8 \\
\hline & & 400 & $1.778 \pm 0.001$ & 41.7 \\
\hline
\end{tabular}

TABLE 2. INHIBITION EFFECTS OF VITAMIN E ON $S_{180}$ ENTITY TUMOR MICE $(X \pm S)$. Lethal dose $\left(L_{50}\right)$ : Vitamin $E=$ $4000 \mathrm{mg} / \mathrm{kg}$;

\begin{tabular}{|c|c|c|c|c|}
\hline \multicolumn{2}{|l|}{ Groups } & $\begin{array}{l}\text { Dose } \\
(\mathrm{mg} / \mathrm{kg})\end{array}$ & $\begin{array}{l}\text { Mean tumor } \\
\text { mass }(\mathrm{g})\end{array}$ & $\begin{array}{l}\text { \% inhibi- } \\
\text { tion }\end{array}$ \\
\hline Control & CG-2 & - & $3.044 \pm 0.001$ & - \\
\hline \multirow{12}{*}{ 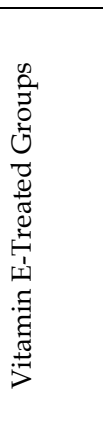 } & \multirow{4}{*}{ TGE-1 } & 50 & $1.600 \pm 0.001$ & 47.5 \\
\hline & & 100 & $1.319 \pm 0.001$ & 56.7 \\
\hline & & 200 & $0.879 \pm 0.001$ & 71.2 \\
\hline & & 400 & $0.510 \pm 0.001$ & 83.2 \\
\hline & \multirow{4}{*}{ TGE-2 } & 50 & $1.650 \pm 0.001$ & 45.8 \\
\hline & & 100 & $1.400 \pm 0.001$ & 54.0 \\
\hline & & 200 & $0.950 \pm 0.001$ & 68.8 \\
\hline & & 400 & $0.670 \pm 0.001$ & 77.9 \\
\hline & \multirow{4}{*}{ TGE-3 } & 50 & $1.530 \pm 0.001$ & 49.7 \\
\hline & & 100 & $1.351 \pm 0.001$ & 55.6 \\
\hline & & 200 & $0.842 \pm 0.001$ & 72.3 \\
\hline & & 400 & $0.568 \pm 0.001$ & 81.3 \\
\hline
\end{tabular}

\section{Conclusion}

Our results suggest that vitamin E and vitamin C (in a lower rate) has inhibitory behavior on the growth of sarcoma in mice. In particular, for dosages on the order of $400 \mathrm{mg} / \mathrm{kg}$ and $100 \mathrm{mg} / \mathrm{kg}$ we obtained stronger effects. Thus, our results suggest a combatively stronger effect of vitamin $\mathrm{E}$ and that dosages could play an important role in the inhibitory properties of sarcoma 180, but the mechanism remains unclear. We suggest that stronger anti-tumor effect of vitamin $\mathrm{E}$ in relation to vitamin $\mathrm{C}$ is due to different mechanisms of anti-tumor action between these molecules. Vitamin $C$ modulates the activities of phagocytes, the production of cytokines and lymphocytes that destroys the tumor cells. On the other hand, vitamin E plays an important role in the differentiation of immature T cells in thymus. On the other hand, the dynamics of penetration of vitamins and drugs shows that a principal route of molecular penetration in cells is through lipid-rich intercellular routes
[14-15], the cell penetration of water-soluble vitamin $\mathrm{C}$ in tumors is very low. A substance having good lipid solubility diffuses well across the cells. Thus, it has been assumed that the vitamin E permeates well since this vitamin is very lipophilic. Probably this particular property makes it more effective as antitumor agent. These results suggest that vitamin $\mathrm{E}$ is a potent anticancer nutrient for promoting health.

\section{Acknowledgments}

We acknowledge financial support from $\mathrm{CNPq}$ and Faperj (Brazil).

\section{Competing Interests}

The authors have declared that no competing interest exists.

\section{References}

1. Ströhle A, Hahn A. Vitamin C and immune function. Med Monatsschr Pharm. 2009; 32: 49-54.

2. Wintergerst ES, Maggini S, Hornig DH. Immune-enhancing role of vitamin C and zinc and effect on clinical conditions. Ann Nutr Metab. 2006; 50: 85-94.

3. Preedy VR; Watson RR; Sherma Z. Dietary Components and Immune Function (Nutrition and Health). Totowa, NJ: Humana Press. 2010; 36: 52

4. Cunningham-Rundles WF, Berner $Y$, Cunningham-Rundles S. Interaction of vitamin $C$ in lymphocyte activation: current status and possible mechanisms of action. In: Cunningham-Rundles S, ed. Nutrient Modulation of the Immune Response. NY: Marcel Decker. 1993: 91-103.

5. Moriguchi S, Muraga M. Vitamin E and immunity. Vitam. Horm. 2000; 59: 305-36.

6. Schafer ZT., Grassian AR., Song L., Jiang Z., Gerhart-Hines Z., Irie HY., Gao S., Puigserver P., Brugge JS. Antioxidant and oncogene rescue of metabolic defects caused by loss of matrix attachment. Nature 2009; 461: 109-113.

7. Liu D, Liu A. Administration of vitamin E prevents thymocyte apoptosis in murine sarcoma S180 tumor bearing mice. Cell Mol Biol 2012, 15: 1671-1679.

8. Johannes PM., Vogelaar D.M.S, Eleanor Erlichman B.S. Significance of Ascorbic Acid (Vitamin C) for the Growth in vitro of Crocker Mouse Sarcoma 180. Am. J. Cancer, 1937; 31: 283.

9. Pollia JA. Observations on Rats Treated with Cevitamic (Ascorbic) Acid. Radiology 1935; 25: 338.

10. Stock C.C, Clack D.A, Phylips F.S. Sarcoma 180 inhibition screening data. Cancer Research-supplement, 1955; 2: 2-3.

11. Komiyama K, Funyama S. Antitumor agents. In: Omura S, ed. The search for bioactive compounds from microorganisms. Springer Verlag 1992: 79- 97.

12. Snedecor G.W, and Cochran W.G. Statistical Methods, 6th edition. Ames, Iowa: Iowa State University Press. 1967.

13. Rivas CI, Zúñiga FA, Salas-Burgos A, Mardones L, Ormazabal V, Vera JC. Vitamin C transporters. J Physiol Biochem. 2008; 64: 357-75.

14. Tojo K. Mathematical modelling of transdermal drug delivery. J. Chem. Eng. Japan 1987; 20: 300.

15. Manitz R., Lucht W, Strehmel K, Weiner E, Neubert R. On mathematical modeling of dermal and transdermal drug delivery. J. Pharm. Sci. 1998; 87: 873. 